\title{
A Book Reviews of Foucault's Discipline and Punish with Educational Refletions
}

\author{
Zhaohao Nian \\ Faculty of Education, Palacky University, Olomouc, Czech Republic \\ Email: zhaohao.nian02@upol.cz
}

How to cite this paper: Nian, Z.H. (2021) A Book Reviews of Foucault's Discipline and Punish with Educational Refletions. Open Access Library Journal, 8: e7466. https://doi.org/10.4236/oalib.1107466

Received: April 28, 2021

Accepted: May 25, 2021

Published: May 28, 2021

Copyright $\odot 2021$ by author(s) and Open Access Library Inc.

This work is licensed under the Creative Commons Attribution International License (CC BY 4.0).

http://creativecommons.org/licenses/by/4.0/

\section{(c) (i) Open Access}

\begin{abstract}
Foucault is the original author of the book (Surveiller et punir: Naissance de la prison), and the original edition is written in French [1]. And then the English translation of its title was changed to Discipline and Punish by translator Alan Sheridan [2]. At the suggestion of the original author Foucault, the title of the book uses "discipline" because Foucault was interested in the richness of the word to express both "standardized training" as a technique of social power and "discipline" when appropriate. The book's heart discusses the operation mechanism of control in modern society with punishment and discipline. Based on the birth of the prison process, detailed and profoundly discusses the how as a form of punishment power to change. According to Foucault's theory, the punishment ways have changed from direct destruction of the flesh to control the soul's transition. At the same time, in Foucault's view, modern society is essentially a disciplined society. It can make people obedient without actually punishing them. The philosophical wisdom in this also brings a lot of educational reflections.
\end{abstract}

\section{Subject Areas}

Philosophy, Education

\section{Keywords}

Foucault, Discipline, Punish, Education

\section{Introduction}

As for the framework of this book, first of all, Foucault examined the history of punishment power. Since the birth of power, the owner of power has tried to bring the will to power into all aspects of human society, trying to exert the influence of power on every individual that makes up the social organism, making them 
submit to power, and making them become the concrete objects for power relations to play a full role. Therefore, the history of the development and operation of power is also the history of the objectification of everything in the world. The first part is: Torture. This part shows us the cruel penal system of France in the 18th century and before, the typical representative of the guillotine, which executed the prisoners in public. It was a visually striking public performance intended to demonstrate the absolute authority of the monarch. But the practice is increasingly showing its drawbacks not least that unjust punishment tends to incite widespread unrest. Torture is a kind of punishment, of course, it also outlined in detail the nature of the sentence and characteristic, summarized in terms of "punishment" is the ruler based on their understanding, to reveal the "facts," the purpose of the power, and suppressing dissent, and adopt a can affect society, on behalf of the "truth" means the power of technology. The second part is: punishment. Into the 18th century, due to the enlightenment and the influence of social change, torture is seen as a symbol of tyranny and brutal monarchs, centering on the punishment of the corresponding changes that have taken place in the whole judicial system.

To adapt to the social common ideas and requirements, monarch maximum devolution to on behalf of the public power of judicial officials, about some of the experts in science are the result of the judicial trial, punishment to the purpose of protecting society. At the same time, punishment began to be mild; that is, punishment is no longer arbitrary, direct, brutal, and becomes a mechanism to use symbols, interests, time to play a function, but still should be regarded as the power technology acting on the body. The third part is: discipline. Accompanied by the change of punishment is another means of power technology: the general use of discipline, which is admonished to conform to the rules. The rules here may be the law, may also be the rules and regulations of various occasions. To ensure Social members will adopt the effect of discipline, hierarchical monitoring, standardized adjudication, inspection, and other means. With the in-depth application of disciplinary standards, people's production, life, and even society have become a panoramic open machine. Every subtle activity of the body will be interfered with by the ubiquitous power effect. The benefit of this kind of circumstance is the power of social members got integration and arrangement. Improve the operation efficiency, are more likely to achieve the desired power specific targets, the defect is power, but the technology is not. Their look or rhetorics, reasonableness, and fair, let a person, especially for details of oppression and control, faded into a blind operation of the machine on the small parts, will be crushed, change at any time. The fourth part is: Prison. Prison imprisons monitors, recognizes, and treats prisoners, which is the ultimate of the comprehensive application of the two power technology means of punishment and discipline, and regarded as a thorough and severe system. But the effectiveness of prisons is questionable: they do not reduce crime; the situation from detention to release creates recidivism; Prison creates an environment of delinquency. So fundamentally, prisons are not simply to deter illegal activities but to distinguish 
them, create and provide them with a universal economic mechanism. The so-called justice represented by the prison is an excuse and tool of class rule. The "universality" of prisons makes punishment natural and acceptable through contract theory, through the operation of all levels of society, and through the mixing of correctional art and punishment power. Society has also acquired the structure of prison. Individuals are subject to the body and control of multiple incarceration mechanisms and are the effects and tools of complex power relations.

To understand Foucault's theory, one must firstly distinguish between two concepts: traditional society and modern society. Traditional power can only control people's bodies but cannot control people's minds. It can only intimidate people through cruel punishment to gain their obedience. But the power of modern society, but incarnate in knowledge, let us take the initiative to identify with it, obey it. We're in control, but we think we're free. This control of power is silent, but it is firmer and more successful. There is a particular word to describe the evolution between traditional and modern societies: modernization. Europe was the first place in the world to modernize. There were several essential milestones on their road to modernization. First of all, after the Renaissance and the Enlightenment in Europe, the tendency broke the church's ideological constraints on people. People began to use their reason to pursue truth and happiness. The industrial revolution brought about big machine production, and people discovered the influential power of science and technology. The bourgeois revolution overthrew the feudal monarchy and established modern democracy. In the mainstream view, modernization is a historical process of rapid progress. Because of modernization, scientific and technological progress is emerging in an endless stream, society changes with each passing day and living standards are rising steadily. Under the guidance of reason and science, Progressives believed that a free, democratic, and prosperous utopian society could eventually be built. But among the highly critical philosophers, things are not so simple. They carry on the deep reflection, and the criticism to the modern flaunts the rationality, the science, and the progress concept. The German philosopher Nietzsche once had a famous view that civilization is the repression of human nature which profoundly influenced Foucault. In Nietzsche's view, although people have broken free from the power of God, reason, and science have more thoroughly deprived people of their freedom and passion. With the deepening of modernization, this repression and deprivation became more and more rigorous. The managers of society use reason and science to transform nature and want to use them to govern all aspects of society. Through his analysis of torture and the history of prisons, Foucault has a keen insight into the secrets of the workings of power in modern society. In the modern world, management has become more secretive and more effective.

Foucault discovered a breakthrough in the "disciplinary society", which was the prison model designed by the British philosopher Bentham in the 18th century. This is a kind of "panoptic prison", in simple terms; it is a new type of circular prison [3]. The prison consists of a central tower and single cells surrounded 
by it. Standing on the tower, looking over to the prisoner's cell, the prisoner's every move can be clearly seen. But standing in the cell, only the central tower can be seen. There are no lights in the tower, and it is impossible to determine whether there are prison guards in the tower. If you are a prisoner in a cell, a fear of being watched will enter your heart, reminding you to be honest all the time. The great thing about this circular prison is that it allows prisoners to supervise themselves.

The individualization of punishment is a consequence of new power strategies, including new penal mechanisms, including the following four basic rules. First, the study of punishment mechanism is not limited to its repressive effect and punishment. Still, it puts them in the context of a series of positive impacts that punishment mechanism may produce, even if these positive effects seem marginal at first sight to view punishment as a complex social function. Second, punishments are analyzed not only as a consequence of legislation or as a representation of social structures but as techniques that have their characteristics in the more general field of other forms of exercise of power. This is to think of punishment as a political strategy. Third, instead of viewing the history of criminal law and the history of the humanities as two independent series, whose mutual overlap seems to have a disturbing or beneficial effect? In short, transforming the technology of power will be into a humane penal system and trigger a human understanding. Fourth, to try to find out whether the entry of the soul into the criminal justice arena and the entry of a body of scientific knowledge into the practice of law are the result of changes in the way in which power relations interfere with the body. In short, he tries to study the variation of punishments based on a kind of physical-power technology, to read from it a common history of power relations and of object relations.

From Foucault ideas in this book by comparison with the present education reality, monitoring means of discipline in the class hierarchy is very typical and common. In a class of architecture, the teachers and students are not in the same subject status, teachers in the classroom for students to monitor rights and qualifications, in fact, when he came into the classroom the special space has already been given because the platform is higher than the student seat, this design is very easy to teachers to monitor all the students in class, it is a reflection on the construction of discipline power. It is also a special case of panoptic prison. The teacher standing on the platform is the embodiment of knowledge or power. The teacher represents the knowledge selected in the textbook and the mainstream values and power of the society. The teacher's monitoring of each student's performance in class is just an attempt to discipline the students into a "docile body" that meets the requirements of social power. This kind of discipline education makes students unconsciously controlled by rules or disciplines, making it convenient for them to manage students uniformly. However, the objects of discipline are also easy to lose their independence and autonomy. Therefore, the way and degree of discipline and respect for students' personality differences are also significant. In school, in class, is filled with discipline and regulations, there 
is a clear written, has established, but without exception are in line with the social power constraint and discipline purpose, from the perspective of the nature of punishment form, there are two types of school discipline, it is clearly written restrictions, students once violated the provisions of this will be very severe punishment. The other is ambiguous standards. For example, there is always a group of top students and average students in a class, but the overall boundaries of the division are not very clear. Nevertheless, in the course of daily learning, the criteria for eligibility are clear. As for the violations of unqualified students, we learn from Foucault's view of rewards and punishments in terms of discipline in this book. Punishment is mainly aimed at correction and has the function of narrowing the gap.

Foucault proposed when teachers are forced to use punishment, they could try firstly to win students' hearts, which is very helpful. Drawing on Foucault's example in this book, the public school has a complete system of rewards and punishments: students can use rewards to avoid punishments. It can be seen that teachers can give students a transition zone when evaluating rewards or punishments so that students can see that the punishment result of their own wrong behavior may be transformed into the possibility of rewards through some feasible correction methods. In addition, Foucault mentioned a fact: It is not the crime that alienates people from society. On the contrary, the crime occurs because the perpetrator is different or the lower class in the society. This also inspires educators a profound educational question to think about the educational issue. It is often difficult for underachievers in a class to make progress. About the profound reason for their unsociability, is it just because of their motivations or academic achievements? As a teacher, it is crucial to discipline students appropriately. However, in the process of discipline, communication and evaluation between teachers and students can also learn from Foucault's views and obtain the art and philosophy of education.

\section{Conflicts of Interest}

The author declares no conflicts of interest regarding the publication of this paper.

\section{References}

[1] Foucault, M. (1975) Surveiller et punir: Naissance de la prison. Éditions Gallimard, Paris.

[2] Foucault, M. (1979) Discipline and Punish: The Birth of the Prison. Vintage Books, New York.

[3] Bentham, J. and Milne, A.T. (2017) Correspondence of Jeremy Bentham, Volume 4. UCL Press, London. https://doi.org/10.2307/j.ctt1qnw8kd 